\title{
KIBLAT DAN KAKBAH DALAM SEJARAH PERKEMBANGAN FIKIH
}

\author{
Mutmainnah \\ FAI UCY
}

\begin{abstract}
A description of the history and fiqh of Qibla cannot be separated from the site of the Ka'bah in Mecca. From there it can be known the problems experienced by the ummah when facing the problem of the correct direction of prayer, especially from those who live far from the Ka'bah. Its history also confirms that as the science and its supporting technology are improving in account with fiqh terms, both are important steps to determine the accuracy of the Qibla direction.
\end{abstract}

Keywords; Kiblat, Kakbah, fiqih, History

Abstrak: Penjabaran tentang sejarah dan fikih kiblat tidak bisa dilepaskan dari situs kakbah di Mekkah. Dari situ bisa diketahui problematika yang dialami umat ketika menghadapi persoalan arah salat yang benar, terutama dari mereka yang tinggal jauh dari Kakbah. Sejarahnya juga menguatkan bahwa seiring peningkatan ilmu pengetahuan dan teknologi pendukungnya yang bisa dipertanggungjawabkan secara fikih adalah langkah penting untuk akurasi arah kiblat.

Kata kunci; Kiblat, Kakbah, fikih, sejarah

\section{A. Pendahuluan}

Kakbah dikenal juga dengan Bait Allah, atau pusat peribadatan muslimin merupakan bangunan suci yang terletak di kota Mekkah. Bangunan Kakbah berbentuk kubus yang dalam bahasa arab disebut muka'ab. Kakbah kemudian dalam konteks ilmu falak dalam lingkup arah oreintasi beribadah. Posisinya tidak menjadi kajian utama dalam perspektif waktu ibadah. ${ }^{1}$

Dalam The Encyclopedia of Religion dijelaskan bahwa bangunan Kakbah ini terdiri dari batu granit Makkah yang kemudian dibangun dalam bentuk kubus dengan tinggi kurang lebih 16 meter, panjang 13 meter dan lebar 11 meter. Batu-batu yang dijadikan saat itu diambil dari

${ }^{1}$ Perspektif waktu banyak berkaitan dengan kajian hisab rukyat dan perjalanan matahari, lihat Muthmainnah, "Sistem Hisab Menurut Hisab Sullam An-Nayyirain Dalam Perspektif Fikih," Jurnal Ulumuddin Volume 4, Nomor 2, Desember 2014, 57-69; Muthmainnah, "Transformasi Koordinat Bola Langit Ke Dalam Segitiga Bola (Equatorial Dan Ekliptika) Dalam Penentuan Awal Waktu Salat," Jurnal Ulumuddin Volume 5, 
lima sacred mountains, yakni: Sinai, al-judi, hira, olivet dan Lebanon.

Kakbah dan kiblat berkaitan erat dalam fikih Islam terutama dalam penerapan salat. ${ }^{2}$ Meski demikian, sejarah bangunan itu ternyata bisa mundur sangat jauh hingga kedatangan manusia pertama di bumi, yaitu Nabi Adam saw. Oleh karena itu, perjalanan sejarah keduanya perlu didalami lebih lanjut. Seperti yang diutarakan oleh Cipto perjalanan sejarah perkembangan Hukum Islam tidak bisa melepaskan dari situasi yang melingkupi dalam sejarah. 3

\section{B. Kakbah pada masa Pra-Islam}

Azhari menjelaskan Kakbah menurut bahasa adalah bait al-Harām di Mekkah, al-Ghurfah (kamar), kullu baitin murabba'in (setiap bangunan yang berbentuk persegi empat). Nama lainnya adalah Bait Allāh, Bait al-'Atīq atau rumah tua yang di bangun kembali oleh Nabi Ibrahim dan puteranya Ismail atas perintah Allah SWT.4

Penelusuran yang dilakukan oleh kaum mufassirin dan lainnya mengatakan tidak ditemukan teks yang menyebutkan siapa pendiri pertama dari Kakbah itu. Qur'an hanya menyebutkan bahwa Kakbah adalah rumah pertama yang diperuntukkan bagi manusia untuk beribadah kepada Allah seperti yang telah disebutkan dalam Q.S. Ali Imran (3): 96. hal ini dikarenakan Nabi Ibrahim As bersama putranya Nabi Ismail hanya membangun kembali atau meninggikan dasar-dasar Baitullah. ${ }^{5}$

Menurut Yaqut Al-Hamami menyatakan bahwa bangunan Kakbah berada di lokasi kemah Nabi Adam As setelah diturunkan Allah SWT dari surga ke bumi. Nabi kemudian dianggap sebagai peletak dasar bangunan Kakbah di bumi. Kemudian setelah Nabi Adam wafat, bangunan tersebut di angkat kelangit dan lokasi itu dari masa ke masa di agungkan dan disucikan oleh para Nabi.

Pada di zaman Nabi Nuh as, Kakbah ini pernah tenggelam dan

\footnotetext{
Nomor 2, Desember 2015, 11-23

2 Muthmainnah, "Falak Dan Ilmu Yang Berkaitan Dengannya," Jurnal Ulumuddin Volume 6, Nomor 1, Juni 2016, h. 49-6o

3 Cipto Sembodo, "Reintroduksi Hukum Islam Dalam Wacana Kebangsaan," Unisia: Jurnal Ilmu-ilmu Sosial, Vol 31, No 69 (2008), h. 231-239

4 Susiknan Azhari, Ilmu Falak (Yogyakarta: Suara Muhammadiyah, 2007), h. 41. 5 Ibid.
} 
runtuh bangunannya hingga datang masa Nabi Ibrahim as bersama anak dan istrinya ke lembah gersang tanpa air yang ternyata di situlah pondasi Kakbah dan bangunannya pernah berdiri. Lalu Allah swt memerintahkan keduanya untuk mendirikan kembali Kakbah di atas bekas pondasinya.

Dalam sejarahnya pada pembangunan Kakbah itu, Nabi Ismail As menerima hajar așwad (batu hitam) dari malaikat Jibril di Jabal Qubais, lalu meletakkannya di sudut tenggara bangunan. Meski demikian, The Encyclopedia of Religion menilainya tidak berwarna hitam, melainkan merah kecoklatan (gelap).

Hajar Aswad ini merupakan batu sakral oleh umat Islam. Mereka mencium atau menyentuh saat melakukan tawaf karena nabi Muhammad SAW juga melakukan hal tersebut. Pensakralan tersebut bukan dimaksudkan untuk menyembahnya, tetapi selaras dengan tujuan ibadah kepada Allah SWT. meski tidak diwajibkan, tetapi mengikuti sirah Nabi menjadi keutamaan dalam hal ini.

Ketika itu Kakbah belum berdaun pintu dan belum ditutupi kain. Orang pertama yang membuat daun pintu Kakbah dan menutupinya dengan kain adalah raja Tubba' dari dinasti Himyar (pra Islam) di Najran (daerah Yaman). Setelah Nabi Ismail wafat, pemeliharaan Kakbah dipegang oleh keturunannya, lalu Bani Jurhum, lalu bani Khuza'ah yang memperkenalkan penyembahan berhala. Selanjutnya pemeliharaan Kakbah dipegang oleh pemuka kabilah Quraisy yang merupakan generasi penerus keturunan Nabi Ismail. ${ }^{6}$

Menjelang kedatangan Islam, Kakbah dipelihara oleh Abdul Mutallib, kakek Nabi Muhammad SAW. Ia menghiasi pintunya dengan emas yang ditemukan ketika menggali Sumur zam-zam. Kakbah di masa ini, sebagaimana halnya dengan sebelumnya, menarik perhatian banyak orang. Abrahah, gubernur Najran, saat itu merupakan daerah bagian kerajaaan Habasyah (sekarang Ethiopia) memerintahkan penduduk Najran, yaitu bani Abdul Madan bin Ad- Dayyān Al-Ḥārisi yang beragama nasrani beraliran Jacobi (salah satu sekte agama Kristen di Timur Tengah)

${ }^{6}$ Ibid. 
untuk membangun tempat peribadatan gereja seperti bentuk Kakbah di Makkah untuk menyainginya. Bangunan itu di sebut bī'ah, dan dikenal sebagai Kakbah Najran. Kakbah ini diagungkan oleh penduduk Najran dan dipelihara oleh para uskup. ${ }^{7}$

Upaya penghancuran juga pernah terjadi. Raja Abrahah bermaksud untuk menghancurkan Kakbah di Makkah dengan pasukan gajah, namun upaya itu gagal. Pasukannya lebih dahulu dihancurkan oleh tentara burung yang melempari mereka dengan batu dari tanah yang berapi sehingga mereka menjadi seperti daun yang dimakan ulat. Kejadian itu dijelaskan dalam Qur'an pada surah Al-Fil.

Bangunan pusaka purbakala dalam Islam itu telah semakin rapuh dimakan waktu, sehingga banyak bagian-bagian temboknya yang retak dan bengkok. Selain itu Makkah juga pernah dilanda banjir hingga menggenangi Kakbah dan meretakkan dinding-dinding Kakbah yang memang sudah rusak. Pada saat itu, kaum Quraisy yang terkemuka di Mekkah berpendapat perlu diadakan renovasi bangunan Kakbah untuk memelihara kedudukannya sebagai tempat suci. Dalam renovasi ini turut serta pemimpin-pemimpin kabilah dan para pemuka kaum di Mekkah lainnya. Sudut-sudut Kakbah kemudian dibagi empat bagian, tiap kabilah mendapat satu sudut yang harus dirombak dan dibangun kembali. ${ }^{8}$

Ketika sampai pada tahap peletakkan Hajar Aswad mereka berselisih tentang siapa yang akan meletakkannya, kemudian pilihan mereka jatuh ke tangan salah satu warga yang dikenal sebagai al-Āmin (yang jujur atau terpercaya) yaitu Muhammad bin Abdullah sebelum menjadi Rasulullah SAW.

Setelah penaklukan kota Mekkah (Fath al-Makkah), pemeliharaan Kakbah dipegang oleh kaum muslimin. Dan berhala-berhala sebagai lambing kemusyrikan yan terdapat disekitarnya pun dihancurkan oleh kaum muslimin. Keutamaannya pun nyata dengan adanya wahyu perintah salat menghadap Kakbah. Awalnya kewajiban dilaksanakan 
sesuai arah Baitul Makdis di Palestina. Hal ini dilakukan berhubungan kedudukannya masih dianggap yang paling istimewa bagi semua agama samawai dan Kakbah masih dikotori oleh beratus-ratus berhala yang mengelilinginya.

Secara pribadi dan sebelum adanya wahyu, dalam sebuah riwayat, sekalipun Rasulullah salat menghadap Baitul Makdis, jika berada di Mekkah Rasulullah saw berusaha untuk tetap salat menghadap ke Kakbah. Caranya adalah dengan mengambil posisi di sebelah selatan Kakbah. Dengan menghadap ke utara, maka selain menghadap Baitul Maqdis di Palestina, beliau juga tetap menghadap Kakbah.

Ketika umat berhijrah ke Madinah, maka menghadap ke dua tempat yang berlawanan arah menjadi mustahil. Dan Rasulullah saw sering menengadahkan wajahnya ke langit berharap turunnya wahyu untuk menghadapkan salat ke Kakbah. Demikianlah Rasulullah pernah menghadap kiblat ke Baitul Maqdis ketika beliau ada di Mekkah dan Madinah hampir kurang lebih 17 bulan sebelum turunlah QS. Al-Baqarah (2): 144 .

\section{Kakbah dan Kiblat pada Masa Kedatangan Islam}

Asy-Syarbini dalam Putra telah menegaskan, "Kiblat disini adalah Kakbah.”9 Kiblat telah identik dengan Kakbah. Dalam bahasa arab bermakna menghadap atau arah, sehingga kaum muslimin menghadap ke arahnya ketika salat. Dalam Quran sebagai sumber fikih di awal kedatangan Islam melalui Muhammad saw, maknanya telah menjadi luas.

\section{Pengertian kiblat}

Adapun kata kiblat, Secara etimologi, berasal dari bahasa arab قبلة Itu adalah bentuk masdar dari kata kerja قبل- يقبل berarti menghadap. 10 Ketika berbicara kiblat secara istilah, Para ulama memberikan definisi yang bervariasi tentang arah kiblat, meskipun pada dasarnya hal tersebut berpangkal pada satu obyek kajian, yakni Kakbah.

9 Muhammad Al-Farabi Putra, "Arah Kiblat Dalam Persfektif Imam Madzhab," http://if-pasca.walisongo.ac.id/wp-content/uploads/2018/o4/Arah-Kiblat-DalamPersfektif-Imam-Madzhab.docx

1o Ahmad Warson Munawir, al-Munawir Kamus Arab-Indonesia (Surabaya: Pustaka Progresif, 1997), h. 1087-1088. 
Dahlan et.al. mendefinisikan kiblat sebagai bangunan Kakbah atau arah yang dituju kaum muslimin dalam melaksanakan sebagian ibadah. Dahlan yang mendefinisikan kiblat sebagai bangunan Kakbah atau arah yang dituju kaum muslimin dalam melaksanakan sebagian ibadah. Kakbah adalah bangunan suci kaum muslimin atau tempat peribadatan paling terkenal dalam Islam yang yang berbentuk kubus yang terletak di tengah- tengah masjidil haram di kota Mekah. ${ }^{11}$

Harun Nasution et.al. mengartikan kiblat sebagai arah menghadap pada waktu salat. ${ }^{12}$ Mochtar Effendy mengartikan kiblat sebagai arah salat, arah Kakbah di kota Makkah.13 Di Ensiklopedi Islam, kiblat adalah suatu arah tertentu kaum muslimin mengarahkan wajahnya dalam ibadah salat. ${ }^{14}$

Dalam ilmu falak, pengertiannya semakin menukik. Bagi Khazin, Kiblat adalah arah Ka'bah di Makkah yang sedang melakukan shalat, sehingga semua gerakan shalat, baik ketika berdiri, ruku' maupun sujud senantiasa berimipit dengan arah itu. Dalam penjelasan lanjutan, kiblat menjadi arah atau jarak yang terdekat sepanjang lingkaran besar yang melewati kota Makkah (Kakbah) dengan tempat kota yang bersangkutan. ${ }^{15}$

Zainal mengikuti pendahulunya. Ia mendefinisikan arah kiblat merupakan arah ke Kakbah mengikuti jarak terdekat bulatan besar globe Bumi. Keperluan utamanya ketika melaksanakan Ibadat fardu seperti salat, pengebumian jenazah dan sunat ketika berdoa, penyembelihan dan yang berkaitan dengannya. ${ }^{16}$

Kata kiblat dan kakbah banyak ditemukan dalam quran dan hadis. Arti pentingnya juga diakui dalam beribadah yang dikuatkan melalui sumber fikih yang sama juga.

${ }^{11}$ Abdul Azis Dahlan, et al., Ensiklopedi Hukum Islam (Jakarta: PT Ichtiar Baru Van Hoeve, Cet. Ke-1, 1996), h. 944. h. 563.

${ }^{12}$ Harun Nasution, et al., Ensiklopedi Hukum Islam (Jakarta: Djambatan, 1992), $\mathrm{V}: 49$

13 Mochtar Effendy, Ensiklopedi Agama dan Filsafat (Palembang: Unsri, 2001),

14 Depag RI, Ensiklopedi Islam (Jakarta: CV. Anda Utama, 1993), h. 629.

15 Muhyiddin Khazin, Ilmu Falak Dalam Teori dan Praktek (Yogyakarta: Buana Pustaka, 2005). h. 47

16 Baharuddin Zainal, Ilmu Falak (Kuala Lumpur: Dewan Bahasa dan Pustaka, 2004), h. 60 
1. Al- Qur'an

Di dalam quran telah disebutkan kata tersebut. Pengertiannya ternyata tetap berkaitan dengan arah dan tempat salat. Pengertian pertama muncul di QS. Al-Baqarah [2]: 142 sebagai berikut;

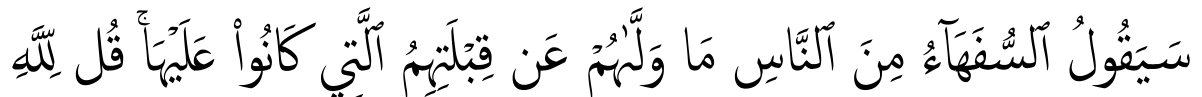

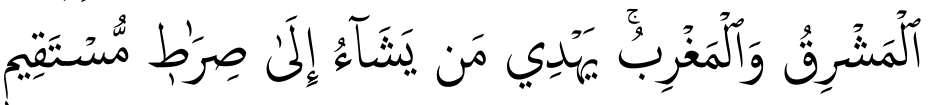

Orang-orang yang kurang akalnya diantara manusia akan berkata: "Apakah yang memalingkan mereka (umat Islam) dari kiblatnya (Baitul Maqdis) yang dahulu mereka telah berkiblat kepadanya?" Katakanlah: "Kepunyaan Allah-lah timur dan barat; Dia memberi petunjuk kepada siapa yang dikehendakiNya ke jalan yang lurus"

Artinya sebagai tempat salat terdapat pada QS. Yunus [10]: 87, yaitu;

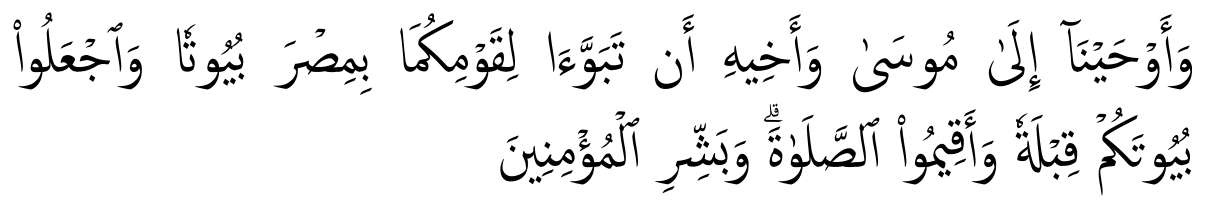

Dan Kami wahyukan kepada Musa dan saudaranya: "Ambillah olehmu berdua beberapa buah rumah di Mesir untuk tempat tinggal bagi kaummu dan jadikanlah olehmu rumah-rumahmu itu tempat shalat dan dirikanlah olehmu sembahyang serta gembirakanlah orang-orang yang beriman"

Banyak ayat al-Quran yang menjelaskan mengenai dasar hukum menghadap kiblat, antara lain firman Allah SWT dalam QS. Al-Baqarah [2] 144;

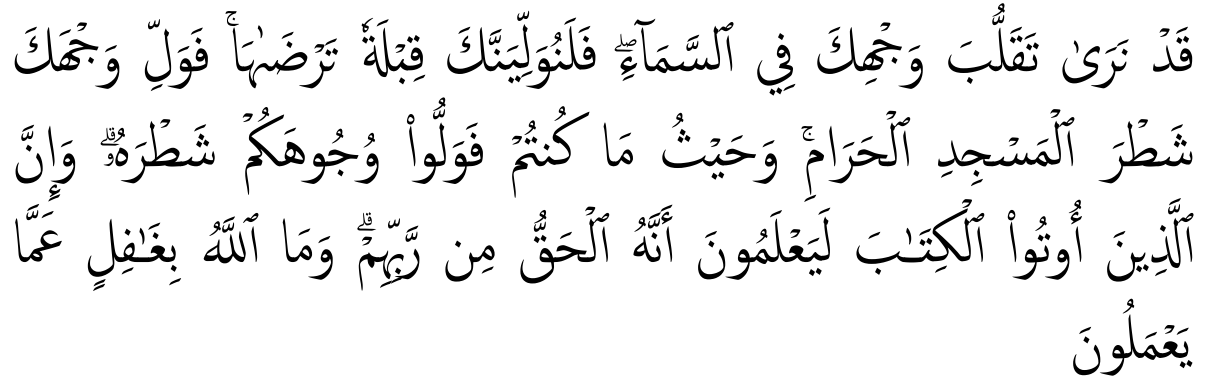

Sungguh Kami (sering) melihat mukamu menengadah ke langit, maka sungguh Kami akan memalingkan kamu ke kiblat yang kamu sukai. Palingkanlah mukamu ke arah Masjidil Haram. Dan dimana saja kamu berada, palingkanlah mukamu ke arahnya. Dan sesungguhnya orang-orang (Yahudi dan Nasrani) yang diberi Al Kitab 
(Taurat dan Injil) memang mengetahui, bahwa berpaling ke Masjidil Haram itu adalah benar dari Tuhannya; dan Allah sekali-kali tidak lengah dari apa yang mereka kerjakan

Putra menafsirkan dari berbagai sumber bahwa ayat itu berisi perintah bagi umat untuk menghadap Kakbah secara tepat ketika melakukan shalat baik yang melihat langsung maupun tidak langsung. Ayat ini menetapkan perpindahan kiblat tersebut dari Baitul makdis ke Masjidil haram. Di sini disebutkan arah Masjidilharam, bukan Ka'bah, sebagai isyarat yang membolehkan kita menghadap "ke arah Ka'bah" pada waktu shalat apabila Ka'bah itu jauh letaknya dari kita dan tidak dapat dilihat. Sebaliknya, jika kita dekat dengan Kakbah, maka kita menghadap Kakbah pada waktu shalat. ${ }^{17}$

Firman Allah lainnya yang berkaitan dengan hukum kiblat ada dalam QS Al-Baqarah [2]:150;

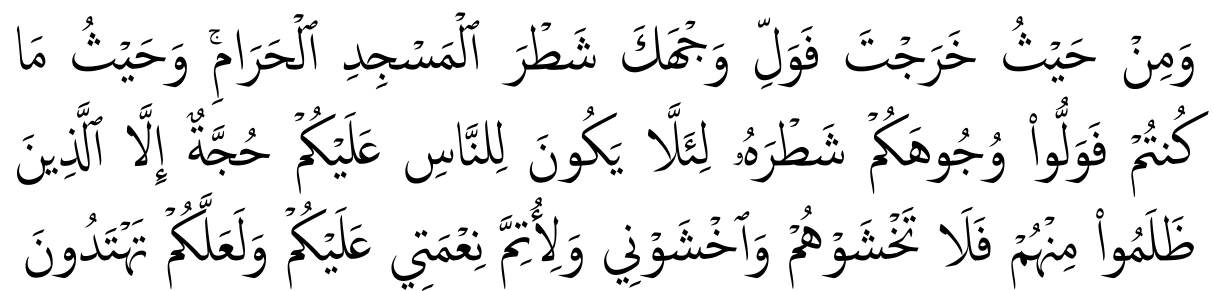

Dan dari mana saja kamu (keluar), maka palingkanlah wajahmu ke arah Masjidil Haram. Dan dimana saja kamu (sekalian) berada, maka palingkanlah wajahmu ke arahnya, agar tidak ada hujjah bagi manusia atas kamu, kecuali orang-orang yang zalim diantara mereka. Maka janganlah kamu takut kepada mereka dan takutlah kepada-Ku (saja). Dan agar Ku-sempurnakan nikmat-Ku atasmu, dan supaya kamu mendapat petunjuk

Allah mengulang ayat "Fa walli wajhaka syaț al- masjid alharām" pengulangan ayat tersebut berfungsi sebagai penegasan betapa pentingnya menghadap kiblat. Pada ayat pertama (Q.S. al-Baqarah 144) ditunjukan kepada orang-orang yang dapat melihat Kakbah secara langsung. Sementara pada ayat kedua (Q.S al-Baqarah: 149-150) ditunjukan pada orang-orang yang berada di luar Masjidil Haram.

Banyak hadis yang berkaitan dengan sikap, sabda, dan perbuatan Rasulullah SAW sebagai penjelas dan aplikasi perintah menghadap kiblat

17 Putra, "Arah Kiblat” 
dalam al-Qur'an. Di antara hadis yang berkaitan dengan penjelasan dan dasar menghadap kiblat adalah hadis yang diriwayatkan oleh Imam Muslim dari sahabat Tsabit bin Anas yang artinya:

"Bahwa sesungguhnya Rasulullah SAW(pada suatu hari) sedang salat dengan menghadap Baitul Maqdis, kemudian turunlah ayat "Sesungguhnya Aku melihat mukamu menengadap ke langit, maka sungguh kami palingkan mukamu ke kiblat yang kamu kehendaki. Palingkanlah mukamu kearah Masjidil Haram”. Kemudian ada seseorang dari Bani Salamah bepergian, menjumpai sekelompok sahabat sedang ruku pada salat fajar. Lalu ia menyeru "Sesungguhnya kiblat telah berubah". Lalu mereka berpaling seperti kelompok Nabi, yakni kearah kiblat". (HR. Muslim).

Kemudian hadis yang diriwayatkan oleh Imam Bukhari dari sahabat Abu Hurairah ra, Rasulullah SAW yang artinya: "Menghadaplah ke kiblat lalu takbirlah"(HR. Bukhari)

Secara umum kumpulan hadis itu menunjukkan kewajiban menghadap kiblat ketika salat. ${ }^{18}$ Sedangkan bagi yang jauh dan tidak dapat melihat bentuk fisik Kakbah maka diperkenankan untuk tidak persis menghadap Kakbah secara yakin tetapi paling tidak secara dann (dugaan kuat). Hal ini diperkuat dengan berdasarkan dalil hadis Nabi yang diriwayatkan oleh Imam Baihaqi;

$$
\text { ما بين المشرق والمغرب قبلة.19 }
$$

Menurut Ibn Umar, apabila barat diposisikan sebelah kanan dan timur sebelah kiri maka arah antara keduanya adalah kiblat. Sementara menurut Ibn Mubarak, arah timur dan barat yang dimaksud adalah bagi penduduk belahan timur. ${ }^{20}$

Hadis menunjukkan bahwa dalam menghadap kiblat (Kakbah) yang diwajibkan bukan bangunan Kakbah, namun mencukupi arahnya saja. Penafsiran lainnya berupa tata cara penentuan arah kiblat dapat dilakukan dengan cara apa saja selama dikatagorikan ijtihad dan selama dapat memersiskan arah kiblat. ${ }^{21}$

\footnotetext{
18 Butar-Butar, Kakbah dan, h. 80.

19 At-Tirmidzi, Sunan At-Tirmidzi (Kairo : Mauqi’ Wa Zarah Al Aw Qaf,t.t), II:75

20 Muhammad bin Ismail ash-Shan'ani, Subul as-Salam (Bandung: Dahlan, t,t), I: 134

${ }^{21}$ Butar-Butar, Kakbah dan, h. 81.
} 
Ketetapan wajib didasarkan pada kesepakatan ulama bahwa kiblat merupakan salah satu syarat sahnya salat. syarat yang harus terpenuhi untuk menjamin kesahan salat. Kiblat bukan syarat wajib atau syarat patokan apakah seseorang terkena kewajiban salat atau tidak.

\section{Kakbah dan Kiblat pada Masa Penyebaran Islam}

Penyebaran Islam dari hingga ujung Persia hingga Andalusia ternyata berdampak dalam salat yang sesuai arah kiblat. Perselisihan pendapat muncul saat kiblat untuk yang tidak di Mekkah. Para ulama berselisih pendapat bagi orang yang tidak melihat Kakbah secara langsung, karena tempat yang jauh dari kota suci. Yang mereka perselisihkan adalah apakah orang yang tidak melihat Kakbah secara langsung wajib baginya menghadap langsung ke Kakbah ataukah menghadap ke arahnya saja.

Sejak saat itu, ummat Islam mempunyai kemampuan menghitung berbagai hal rumit seperti peredaran bulan, perputaran bumi mengelilingi matahari, jarak antar benda langit, dan lain-lain. Semua itu terangkum dalam ilmu Falak. ${ }^{22}$

1. Imam Syafi’i

Mengenai menghadap arah kiblat, imam Syafi'i membagi ke dalam dua cara. Pertama, bagi orang yang mampu melihat Kakbah atau orang yang berada di Makkah, maka ia harus menghadap kiblat dengan benar. Bagi orang yang tidak mampu menghadap arah kiblat karena dalam keadaan buta, maka ia salat menghadap ke arah Kakbah dengan bantuan orang lain. Apabila ia tidak menemukan orang yang mampu membantunya untuk menghadap arah kiblat, maka ia tetap salat dan mengulanginya ketika sudah ada yang membenarkan arah kiblat. ${ }^{23}$

Kedua, bagi orang yang tidak bisa melihat Kakbah atau berada di luar Makkah maka tidak boleh baginya ketika hendak mengerjakan salat, meninggalkan berijtihad untuk mencari Kakbah yang benar, dengan petunjuk bintang-bintang, matahari, bulan, gunung-gunung, arah berhembusnya dan setiap apa saja yang ada padanya yang dapat menjadi

22 Muthmainnah, "Falak Dan"

23 Muhammad Bin Idris as Syafi'i, Al Umm ( Jakarta : CV Faizan, 1982), I: 93-94. 
petunjuk kiblat. ${ }^{24}$

Apabila seseorang telah berijtihad dan menjalankan salat ke arah hasil ijtihadnya, sampai selesai salatnya kemudian dia tahu sesudah selesai salatnya, bahwa sesungguhnya arah kiblatnya itu salah dengan yakin, maka salatnya batal dan wajib mengulangi, kecuali jika dia mengira arah kiblatnya tadi salah, maka tetap sah salatnya. ${ }^{25}$

2. Imam Maliki

Ulama Malikiyah mengatakan bahwa syarat sah salat yang kelima ialah menghadap kiblat dengan adanya tiga (3) syarat:

Pertama, orang tersebut mampu menghadap kiblat. Adapun bagi orang yang tidak mampu menghadap kiblat, seperti halnya sakit sedangkan ia tidak menemukan orang yang dapat menuntunnya ke arah kiblat, maka kewajiban menghadap kiblat tersebut gugur, dan bagi orang tersebut diperbolehkan menghadap selain kiblat.

Kedua orang tersebut dalam keadaan aman, barang siapa yang khawatir akan keselamatan jiwa maupun hartanya dari serangan musuh, maka ia diperbolehkan menghadap ke arah manapun yang ia bisa, dan ia tidak diwajibkan untuk mengulangi salatnya. Ketiga, apabila seseorang dalam keadaan lupa menghadap ke arah kiblat, maka salat orang tersebut tetap sah akan tetapi ia disunnahkan untuk mengulangi salatnya jika salat tersebut adalah salat fardhu.

Adapun ketentuan dalam menghadap kiblat ialah :

a. Bagi orang yang berada di Makkah

Wajib baginya menghadap kiblat ('ain al-ka'bah) secara keseluruhan anggota tubuhnya. Apabila ada sebagian anggota tubuh yang melenceng dari ain al Kakbah maka salatnya tidak sah. Adapun jika orang tersebut berada di tanah haram, maka orang tersebut salat secara berbaris menghadap kiblat, akan tetapi tidak harus persis menghadap hajar aswad. Dan apabila orang tersebut berada di rumah, maka harus berusaha mencari arah kiblat.

b. Bagi orang yang berada jauh dari Makkah 
Kiblat bagi orang yang berada di luar Makkah ialah jihah al-Ka'bah (arah menuju ke Kakbah) baik orang tersebut berada ditempat yang dekat maupun jauh dari Makkah. Maka orang yang salat di luar Makkah hanya cukup dengan menghadap jihat saja, tanpa harus menghadap 'ain alKa'bah. Syaratnya adalah sebagian dari wajahnya menghadap ke arah Kakbah.

Apabila seseorang masuk dalam suatu wilayah, kemudian orang tersebut menemukan mimbar di sebuah masjid, maka orang tersebut cukup menghadap ke arah mimbar tersebut. Namun apabila tidak menemukan mimbar di sebuah masjid dan juga tidak menemukan orang yang adil dan mampu untuk ditanya, maka ia harus memilih salah satu dari empat arah, kemudaian salat menghadap ke arah tersebut. Apabila seseorang mujtahid telah berijtihad, kemudian ketika dalam keadaan salat tampak akan kesalahan ijtihadnya, baik secara prasangka maupun secara yakin, maka ia wajib menghentikan salatnya dengan dua syarat. Pertama orang tersebut dapat melihat yang kedua kemelencengan dari arah kiblat jauh. Apabila kemelencengannya cuma sedikit, maka salat tidak batal akan tetapi wajib berpaling ke arah kiblat.

c. Imam Hambali

Orang salat hubungannya dengan menghadap kiblat, terbagi empat macam: ${ }^{26}$

1. Orang yang yakin. Orang ini penduduk Makkah atau dia melihat Kakbah, maka orang tersebut wajib menghadap Kakbah.

2. Orang yang mendengar kabar. Orang ini bukan penduduk Makkah, atau dia berada di Makkah tapi tidak melihat Kakbah. Adapun kabar tersebut datangnya dari orang yang yakin melihat atau menyaksikan Kakbah. Maka orang tersebut, wajib mengikuti kabar tersebut atau menghadap kiblat sesuai kabar itu, dan dia sendiri tidak perlu berijtihad atau mencari-cari arah kiblat. Begitu halnya dengan orang yang berada dikota dan desa, dia harus mengikuti arah mihrab dan kiblat mesjid.

${ }^{26}$ Al Maqdisy, Al Mughni Fi, II: 272- 273. 
Kiblat mesjid ditentukan oleh orang yang ahli dalam bidang kiblat. Maka hal ini sama dengan kabar yang harus diikuti, tidak perlu berijtihad. Demikian halnya dengan orang yang diberitahu oleh orang yang ahli mengetahui arah kiblat. Baik orang ahli tersebut sedaerah maupun dari daerah lain. Dengan kata lain, kabar tersebut harus diikuti dan tidak usah berijtihad.

3. Mujtahid atau orang yang harus berijtihad dan dia wajib mengikuti ijtihadnya. Hal ini jika dua keadaan di atas tidak ada, sedangkan dia mengetahui dalil atau tanda untuk mendeteksi arah kiblat.

4. Muqallid atau Orang yang harus taklid atau mengikuti hasil ijtihad orang lain. Yaitu orang yang awam atau tidak mampu berijtihad. Sedangkan dia sendiri bukan dalam dua keadaan diatas. Baik orang buta, orang yang tidak mampu berijtihad, dan semua orang yang posisinya jauh dari Makkah, wajib bagi mereka mencari arah Kakbah.

Adapun kewajiban golongan ketiga dan keempat serta semua orang yang jauh dari Makkah ialah mengahadap arah kiblat, bukan ke ain al Kakbah. Imam Hambali juga menjelaskan bahwa semua arah tidak dapat dijadikan arah untuk serta merta mengahadap kiblat dalam melaksanakan salat. ${ }^{27}$

\section{d. Imam Hanafi}

Menurut Imam Hanafi, kiblat adalah 'ain al Kabah. Bagi yang berada di Makkah atau dekat dengan Kakbah, maka sesungguhnya diwajibkanlah seseorang yang hendak melaksanakan salat untuk menghadap ain al Kakbah dengan yakin, selagi itu memungkinkan. Akan tetapi, apabila hal tersebut tidak memungkinkan, maka diwajibkan berijtihad untuk menghadap ke ain al Kakbah. Selama masih berada di Makkah, maka tidak diperkenankan hanya menghadap jihat al Kakbah. Adapun apabila seseorang yang bermukim jauh dari Makkah ia wajib menghadap kiblat dengan jihat al Kakbah tanpa harus ke 'ain al-Ka'bah.

Untuk mengetahui arah kiblat pada suatu tempat ada berbagai macam cara, yaitu dengan menggunakan mihrab yang telah didirikan oleh,

${ }^{27}$ Ibn Taimiyah. Kitab Sifat Salat Min Syarh al-'Umdah Lil Imam Muwafiq adDin Ibn Qudamah (Riyāẹ Dār al-'Āṣimah, 2008), I: 564. 
apabila tidak ada, maka dengan bertanya kepada penduduk setempat. Apabila seseorang tidak dapat menentukan arah kiblat, maka wajib berusaha untuk mencari arah kiblat dan kemudian salat menghadap sesuai hasil ijtihad tersebut. Apabila diketahui usahanya tersebut salah setelah salat, maka tidak wajib untuk mengulanginya. Hal ini sebagaimana pernah dilakukan oleh Nabi dan sahabatnya. Apabila kesalahan tersebut tampak di pertengahan salat, maka ia harus berpaling ke arah yang benar.

\section{E. Penutup}

Indonesia termasuk yang mengalami permasalahan dari sisi jarak terhadap Kakbah. Saat ini masih banyak bangunan masjid tempat salat perlu peninjauan terhadap akurasi arah salat umat. Hal tersebut muncul karena sejak zaman dahulu, kebanyakan orang menandai arah kiblat dengan arah mata angin dan penentuan arah kiblat dilakukan dengan perkiraan dan kebiasaan.

Penyebabnya bersumber pada kekurangan dalam intensi sosialisasi kiblat termasuk penggunaan teknologi modern pendukungnya yang bisa dipertanggungjawabkan secara bersama. Selain itu kendala adat masyarakat juga berpengaruh. Kebanyakan tidak meminta bantuan kepada para pakar. Mereka menyerahkan wewenang itu sepenuhnya kepada tokoh maupun tetua dari kalangan mereka sendiri. Apa yang telah diputuskan, maka itulah yang dianut tanpa pengujian selanjutnya.

\section{Daftar Pustaka}

Azhari, Susiknan. Ilmu Falak. Yogyakarta: Suara Muhammadiyah, 2007. Butar-Butar, Arwin Juli Rakhma. Kabah dan Problematika Arah Kiblat, Yogyakarta: Museum Astronomi Islam, 2013.

Dahlan, Abdul Azis, et al., Ensiklopedi Hukum Islam, Jakarta: PT Ichtiar Baru Van Hoeve, Cet. Ke-1, 1996.

Departemen Agama Republik Indonesia. Al-Qur'an dan Terjemahnya. Semarang: Kumudasmoro Grafindo, 1994.

Departemen Agama RI. Ensiklopedi Islam. Jakarta: CV. Anda Utama, 1993.

Effendy, Mochtar. Ensiklopedi Agama dan Filsafat. Palembang: Penerbit Universitas Sriwijaya, 2001.

Ibn Taimiyah. Kitab Sifat Salat Min Syarh al-'Umdah Lil Imam Muwafiq ad-Din Ibn Qudamah. Riyād: Dār al-'Āṣimah, 2008.

Izzudin, Ahmad. Menentukan Arah Kiblat Praktis. Semarang: Walisongo Press, 2010.

Khazin, Muhyiddin. Ilmu Falak dalam Teori dan Praktik. Yogyakarta: 
Buana Pustaka. 2008.

Maqdisy, Abdullah bin Muhammad bin Qudamah. Al Mughni Fi Fiqh Imām As Sunnah Ahmad Hambal Ash-Shaibani. Beirut : Dar Al Kutb Al-Islāmiyyah, 1991.

Munawir, Ahmad Warson. al-Munawir Kamus Arab-Indonesia. Surabaya: Pustaka Progressif, 1997.

Musonnif, Ahmad. Ilmu Falak. Yogyakarta: Teras, 2011.

Nasution, Harun, et al. Ensiklopedi Hukum Islam. Jakarta: Djambatan, 1992.

Muthmainnah, "Falak Dan Ilmu Yang Berkaitan Dengannya," Jurnal Ulumuddin Volume 6, Nomor 1, Juni 2016, h. 49-60

Muthmainnah, Sistem Hisab Menurut Hisab Sullam An-Nayyirain Dalam Perspektif Fikih, Jurnal Ulumuddin Volume 4, Nomor 2, Desember 2014, 57-69.

Muthmainnah, Transformasi Koordinat Bola Langit Ke Dalam Segitiga Bola (Equatorial Dan Ekliptika) Dalam Penentuan Awal Waktu Salat, Jurnal Ulumuddin Volume 5, Nomor 2, Desember 2015, 1123

Putra, Muhammad Al-Farabi. "Arah Kiblat Dalam Persfektif Imam Madzhab.” http://if-pasca.walisongo.ac.id/wp-content/ uploads/ 2018/o4/Arah-Kiblat-Dalam-Persfektif-Imam-Madzhab.docx

Sembodo, Cipto. "Reintroduksi Hukum Islam Dalam Wacana Kebangsaan," Unisia: Jurnal Ilmu-ilmu Sosial, Vol 31, No 69 (2008), h. 231-239

Syafi'i, Muhammad Bin Idris. Al Umm. Jakarta : CV Faizan, 1982.

Shīrāzi, Abu Ishaq Ibrāhīm 'Alī, Muhammad Bin Idris. al-Muhazzab fi Fiqh imam ash-Shāfi í. Saudi Arabia: Dār al-Kutub al-'ilmiyyah, t.t.

Zainal, Baharuddin. Ilmu Falak. Kuala Lumpur: Dewan Bahasa dan Pustaka, 2004 
Mutmainnah 